Article

\title{
The Linkages between Real Estate Tourism and Urban Sprawl in Majorca (Balearic Islands, Spain)
}

\section{Angela Hof ${ }^{1}$ and Macià Blázquez-Salom ${ }^{2, *}$}

1 Landscape Ecology/Biogeography, Geography Department, Ruhr University Bochum, Universitaetsstrasse 150, 44780 Bochum, Germany; E-Mail: angela.hof @ruhr-uni-bochum.de Research Group on Sustainability and Territory (GIST), Earth Sciences Department, University of the Balearic Islands, Carretera de Valldemossa, km. 7,5, 07122 Palma (Majorca), Spain

* Author to whom correspondence should be addressed; E-Mail: mblazquez@uib.cat; Tel.: +34-971-172-602; Fax: +34-971-172-309.

Received: 5 April 2013; in revised form: 10 May 2013 / Accepted: 17 May 2013 /

Published: 30 May 2013

\begin{abstract}
Financial capitalism has driven profound changes in urban land use patterns in Majorca, at the Balearic Islands (Spain). This archipelago is a major tourist destination located in the Mediterranean basin, with 4,492 $\mathrm{km}^{2}$ of surface area, 1,113,114 inhabitants and 12,316,399 tourists (2011), of whom 29.9\% came from Germany, 24\% from the UK and 19\% from the rest of Spain. Neoliberal state regulation has favored the elite's financial interests in the real estate sector through transport megaproject investment and lifting regional planning restrictions which prevented urban growth. Urban sprawl is becoming increasingly significant for inland Majorca, where intensive tourist resorts had not previously been developed. Urban growth distribution patterns are studied, firstly of suburban development both for tourists and for residential purposes, and secondly of exurban sprawl distribution for isolated dwellings. Recent regional planning relaxation guided by the free market economy and roll-with-it politics aims to promote this urban sprawl as a neoliberal answer to the current crisis of capitalism. In this way, a new model of capital investment in urban spatio-temporal fix, such as countryside villas with swimming pools, is shifting the urban model of this island. The paper identifies the site-specific spatial, temporal and planning pathways through which the actions and decisions of residential tourists and developers buying property in Majorca have driven urban sprawl and vice versa.
\end{abstract}


Keywords: urban sprawl; countryside villas; swimming pools; neoliberal planning; urban growth patterns; financiarization

\section{Introduction}

\subsection{Residential Tourism and Urban Sprawl in a Wider Context}

The concept of "residential tourism" has been used since the late 1970s to describe a development model based on the production of urban land for the construction of real estate property in tourist areas. This tourism-related residential development also describes a complex system where different sorts of leisure mobility converge, whose nature may range from tourism, lifestyle migration to transnational citizenship and multi-residential strategies. The demographic and socio-economic transformations brought about by residential tourism have been discussed elsewhere [1]. The focus of this paper is the material transformation in tourist areas that is related to real estate development. In this way, as some authors have shown, residential tourism becomes a key element of socio-economic tourist modernization, with urban and demographic growth being the most significant expressions of the process [2].

On a European scale, land cover change detected from comparison of CORINE Land Cover data for 1990 and 2000 showed that already highly populated coastal strips in the Mediterranean were hot spots of urban sprawl and fragmentation [3]. This was often linked to the development of second homes and an increasing preference for suburban environments, where more disperse land use and land cover patterns evolve. These new Mediterranean urban landscapes are the opposite of the classical dense Mediterranean urban form and are the outcome of population, economic and housing shifts. New suburban areas are developing outside of the traditional cities and villages. They are characterized by a low density, spacious residential matrix of large plots occupied by gardens and swimming pools. Additionally, a second kind of urban sprawl has been identified; exurban construction for dwelling has occurred in the countryside, even without regulatory planning and within a more spacious residential matrix.

Spain in particular is experiencing a tourist and real estate boom and that has left a deeply profound land use mark. Although tourism-related residential development and second homes make up half of the housing stock in many locations, the phenomenon has been relatively little studied with respect to the actual transformation of the urban landscape and built environment. Not at least, this is due to the fact that this urban and demographic growth is veiled under the general term "tourism" by key stakeholders, diverting the attention to a sector that is a pillar of the Spanish economy, particularly at the local, municipality scale [2]. Active development of newly built second homes mainly occurred in growing mass tourist zones in popular holiday destinations [4]. Foreign ownership (in particular from Germany and the United Kingdom) has played an important role, but subsequently Spaniards have contributed to this new tourist boom. In combination, Spain's entry into the European Union, the emergence of regional government (autonomous communities such as the Balearic Islands) and the wealthier economic conditions in Germany, The Netherlands and the UK have promoted the purchase of second homes in Spain, with a strong concentration in the major tourist areas [4]. This paper starts its argument from the premise that the interaction of international capital flows and demand for 
land - that provides cultural ecosystems services (aesthetic, recreational) and relates to individual freedom of choice and action-is linked to urban land change processes in the distant major tourist areas such as the Balearic Islands and other Mediterranean coastal zones. There, the transformation to a more diversified tourism development, tourist specialization and a new urban model has societal and environmental impacts that are currently discussed in the context of sustainable urban and regional development. The increase in low density housing, accompanied by gardens, and on top of that, public or semi-public green areas like road verges, parks, golf courses and other forms of green recreation sites threaten, among other impacts, the water supply system of whole metropolitan regions [5], intensify conflicts among users, and increase the vulnerability to climate change [6]. In this context, the purpose of the paper is to give insights into the connections between real estate tourism and recent urban sprawl in the Balearic Island of Majorca. Real estate tourism is revealed as a driver of both the expansion of low-density residential areas at the coast in close proximity to existing mass tourist urban centers and as a driver of scattered urban development inland where a new market segment of holiday villas is emerging. The former process is addressed as suburban sprawl in the paper, the latter as exurban sprawl. We understand "holiday villas" to be those dwelling houses used for rental or real estate market purposes.

\subsection{Majorca as a Case Study for the Nexus between Tourism, Land Change and Urban Sprawl}

The Balearic Islands are a major tourist destination in the Mediterranean, attracting 12.3 million tourist arrivals in 2011, which represented a 5\% share of the Mediterranean market. Majorca, the archipelago's largest island and tourist destination, is one of the world's pioneers of mass tourism. The concentration of tourist bed capacity at the coast reflects the sun and beach tourist model of this archetypal mass tourism resort that has attracted sustained tourist flows since the 1960s [7] (Figure 1). Since the mid 1990s, the extension of Majorca's tourist base by the proliferation of second homes, golf courses, yacht and cruising tourism has been marketed under the term "quality tourism" (turismo de calidad). Some authors interpret this development as a move towards a more sustainable, "quality" type of tourism [8], while others have highlighted the negative impact of this new type of tourist boom on environmental indicators [9]. Residential tourism in Majorca is seen as a major reason for the observation that urban expansion during the recent decades has taken mainly a sprawled form, starting first in the established tourist areas and then moving on to the inland and countryside parts of the island.

\subsection{Objectives and Outline of the Paper}

This research aims at identifying site-specific spatial, temporal and planning pathways of the flourishing real estate business and its linkages to the increasing urban sprawl in Majorca. Accordingly, the paper is organized as follows. Section 2 outlines the economic, political and societal circumstances behind what is referred to in the paper as real estate tourism model shift. In this context, it is worth highlighting firstly, the financial purpose of real estate tourism model shift; secondly, considering the transport megaprojects influence in the urban sprawl process; and thirdly, explaining the neoliberal re-framing of the regulatory urban planning framework as a contributing factor to the urban growth process. On this theoretical background, Section 3 presents the exploratory and empirical design to analyze the linkages between real estate tourism and urban sprawl in Majorca. Land cover, demographic 
and housing data are analyzed at the level of municipalities to explore the process and nature of urban expansion in recent decades. At a more detailed spatial scale, suburban and exurban sprawl patterns are analyzed in an attempt to link these with real estate tourism, mainly through taking the presence of swimming pools and the planning permission for holiday villas as indicators for the process which eludes official statistics and is giving methodological difficulties due to a lack of comprehensive data.

Figure 1. Study area, distribution of declared tourist beds and urban sprawl in Majorca.

Data source: Own calculations, based on [10-12].

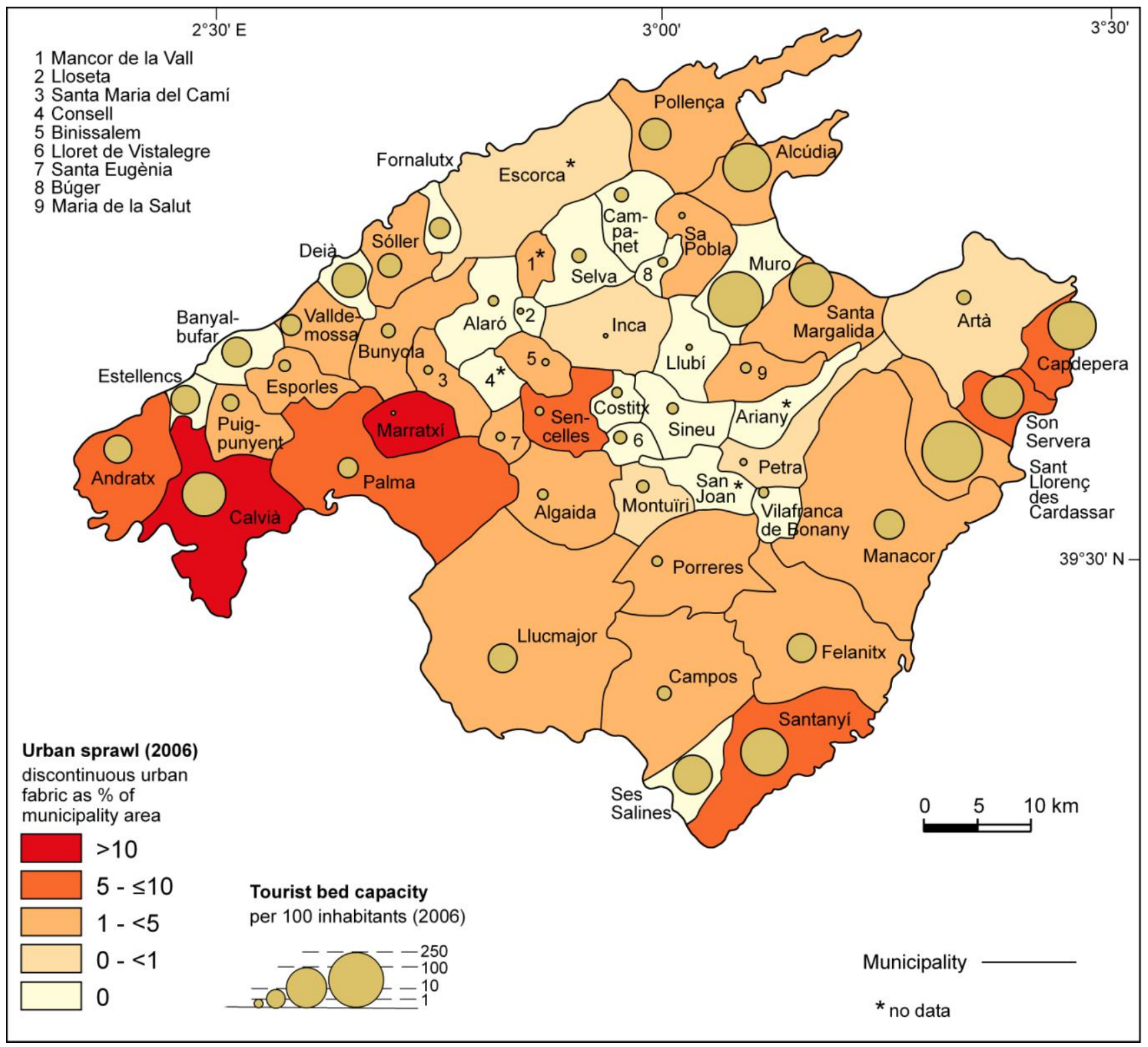

\section{Market and Policy Mainstreams on Tourism and Land Use Planning}

\subsection{Real Estate Tourism Shift}

The driver of the real estate tourism boom observed in Spain and elsewhere has been the establishment of the European Union free trade market and the current crisis, which is pressing periphery countries within Europe, such as Spain, to intensify their economic dependence on the construction and 
tourism sector specializations. Fixing and speeding up the cycles of capital circulation and accumulation are driving the "city as a growth machine" [13]. The secondary circuits of capital accumulation foster urban sprawl and infrastructure development through the investment of capital in the built environment [14] as a mode of capitalist financialisation [15]. This is heightened in the "Spanish model", which is characterised by an urban and tourism "developmentalism" associated with the Euro area [16].

The Balearic Islands and Majorca in particular are hot spots for this development. Majorca positions itself as real estate property market and adds properties' financial attractiveness to its traditional appeal for sun and sea tourism. Majorca has experienced much inward migration, which is reflected in a population increase of $31.5 \%$ between 1990 and 2006. On average, 25\% of the inhabitants in Majorcan municipalities come from other Spanish provinces or from abroad, the highest proportion $(60 \%$ and $46 \%$, respectively) of foreigners are found in the popular resorts of Calvià and Andratx in the southwest of the island. Out of all the Spanish autonomous communities, the Balearic Islands had the highest percentage of real estate sales to foreign people in 2012 [17]. The real estate nature of this process becomes apparent when it is observed that virtually all foreign investments go to the service sector and the construction sector (Figure 2) [18]. These two sectors accumulated almost $90 \%$ of foreign direct investment (FDI) in 2011. Investment in others sectors is negligible. Services particularly include real estate services [19]. Between 2004 and 2007, the mean share of the FDI going to building houses was 51.1\%. Afterwards it fell for 2008-2009 shifting to other services sectors (mainly insurance, 55\% of all the FDI in 2008). Notwithstanding, it recovered from 2010 onwards, joining again the real estate activities share. The anomaly during 2004-2007 among real estate and building sectors is linked to the Spanish construction bubble.

Figure 2. Development of foreign investment in the Balearic Islands and the importance of the real estate activities and housing sector (1993-2011) (Own figure, based on statistical data published by [18]).

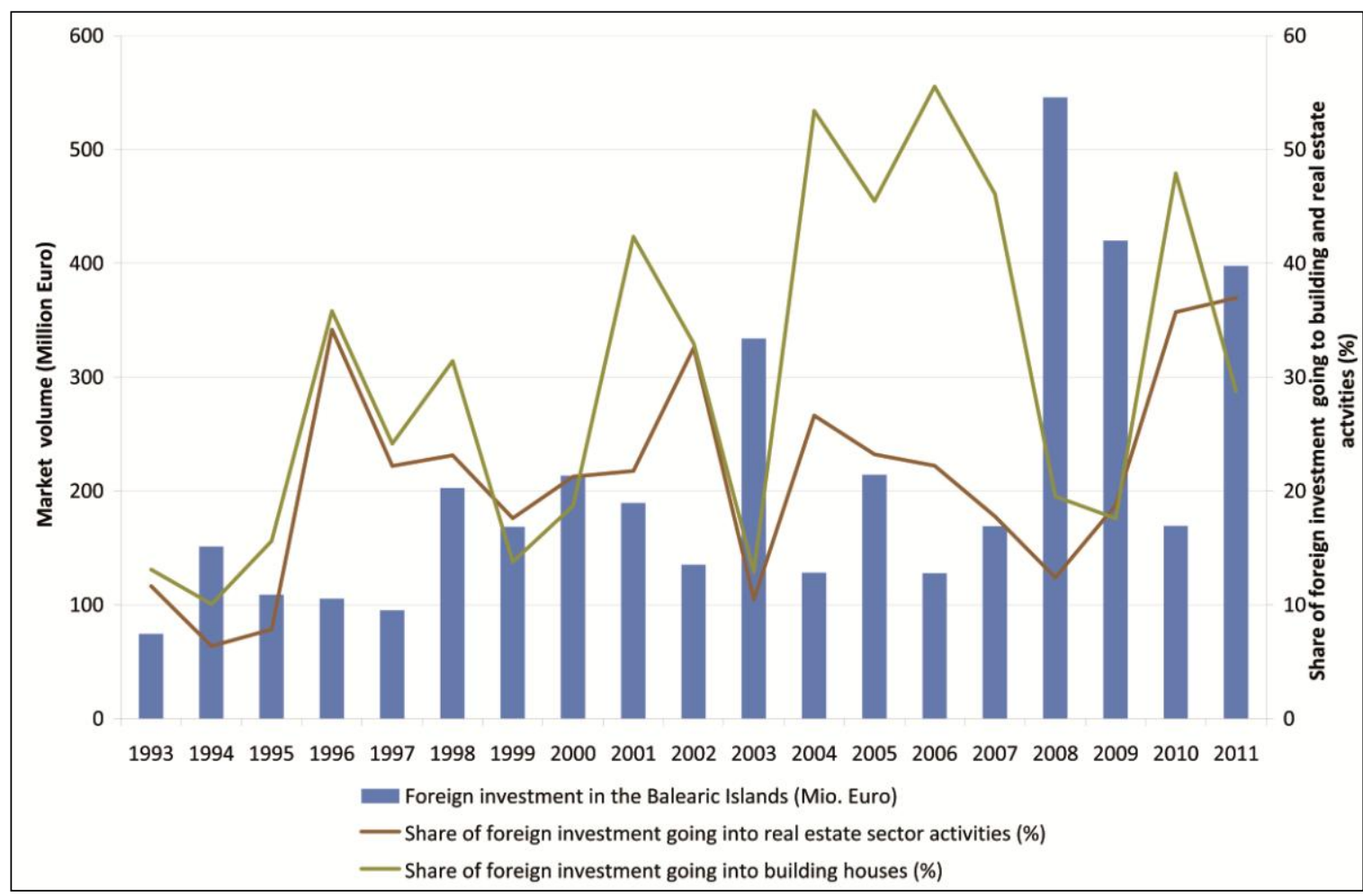


The coastline and the scenic beauty of its mountain ranges are the determining factor behind the highest market prices for residential buildings in Majorca [20]. The result is the growth of the urban areas of the island, with $6.2 \%$ of the island's surface urbanized by 2006 . Since the $1990 \mathrm{~s}$, much of urban growth has had an extensive suburban pattern characterized by a low density, spacious residential matrix of large plots occupied by gardens and swimming pools. The capital movements in which this finds expression shows a hunt for profitability; where profits determine the production of space [21] through speculation, with residential housing as the traded commodity. The Balearic Islands have a unique ability to attract capital from a stimulated global market - in addition to the attraction posed by profits - with commodities associated with high-status lifestyles seen as a mark of distinction [22], linked to a return to rural Arcadia with counter-cultural overtones [23]. These rural retreats are likely to increase social segregation [24] in terms of rural gentrification [22]. Paradigmatic examples can be easily found of global elites choosing Majorca or other Balearic islands to establish their luxury villas and second homes in the countryside. To illustrate it only with one case, Stephan Schmidheiny bought the rural estate of S'Alqueria in Andratx. He created the first Business Council for Sustainable Development (BCSD) and represents those who "have used the discourses of national competitiveness and sustainable development to further the interest of global capital" [25].

\subsection{Transport Megaprojects Influence}

The enlargement of the transport infrastructure in recent years has fostered this urban sprawl [26]. In 2001, during planning for the current airport, it was assumed there would be a demand of 38.6 million passengers in 2015 [27], while the total amount of passengers in 2011 was 22.73 million. Additionally, $108.42 \mathrm{~km}$ of high speed roads and road expansions (new highways, bypasses, enlargements and tunnels) were constructed in Majorca between 2003 and 2007 in order to improve the accessibility to the countryside [28]. Transport megaprojects aim at a frictionless society through high public investment infrastructure that has been characterized by low transparency and a lack of civil society involvement [29]. They constitute a spatio-temporal fix attracting investment capital and extending frontiers for geographical expansion through time-space compression. David Harvey refers to those investments where "a certain portion of the total capital is literally fixed in and on the land in some physical form for a relatively long period of time" (which he considers the physical "fix") that at the same time constitutes a "particular kind of solution to capitalist crises through temporal deferral and/or geographical expansion" (that he understands as the metaphorical "fix") [30].

\subsection{Changes with the Crisis in the Land Use Regulatory Planning}

Majorcan social movements complain about the irregularities and the political corruption linked to the urban growth process, as has been documented by Morey [31]. These campaigns of territorial protection have sound roots in the ecological social movements of the Balearic Islands, since the 1970 's. But it has been criticized as a form of NIMBYism supporting the use of regulations to prevent further development in order to protect their image of the rural idyll. This kind of alliance of interests, for instance in agreement with some residential tourism elites, has occurred in other residential tourism destinations [32]. Assuming these social demands, the Balearic Islands' governments have applied urban, tourist and infrastructural development constraints since the beginning of the current Spanish 
democratic historical period, in order to "regulate and contain the urban growth" [33]. Outstandingly, the first legislation of its autonomous Parliament in 1984 is devoted to the creation of designated areas. As an example of this regulatory legislation, the regional planning act (1999) has kept the urban growth constrained to the surroundings of the existing urban areas, guiding its growth temporally and preventing the urban sprawl. Additionally, the tourist accommodation growth was also curbed in 1999 in order to promote its reconversion and modernization, merely maintaining its stock. The highest quality hotels and the regulated tourist accommodation inland (rural, inland and agro-tourism hotels and holiday villas) were exempt from this moratorium and tourist growth in this market segment was not restricted. But, the last important act promoting territorial protection was promulgated just before the current financial and economic crisis, in 2008, to prevent more golf course construction (23 are already constructed in Majorca) with its additional hotel supply, to protect seven more natural areas in Majorca and to stop the license to develop 11 new urban areas. As a result, these norms have been considered as a "moratorium" to urban and tourism growth [34], effective until the onset of the current crisis.

The neoliberal political answer to the current crisis has made this model change. Conservative governments (from 2011 onwards) have changed the rules towards the deregulation of the urban growth, relaxing or lifting regional planning restrictions which prevented urban growth. Neoliberal capitalism implies deregulation and laissez-faire for the capital interests, with a regulatory reduction of duties and responsibilities of all types (dealing with labor conditions, taxation, environmental duties, etc.) in support of free enterprise, on the grounds of the presumed need to create the conditions that will foster investment, competition, innovation and growth. The role of the State is thus adapted to the neoliberal schemes that establish its roll-back [35], roll out regulatory measures through this new legislation that supports privatization and marketization [36], or even its roll-with-it strategy as a result of the elite reaction to widespread contestation (in our case for territorial protection) to neoliberal regulation [37]. In Majorca, this means that real estate investors (for example, family-owned Balearic hotel chains) influence the formulation of urban and tourist planning regulations at the regional and local level.

Whereas elites practicing residential tourism are interested in the use value of real estate and give support to urban planning restrictions, the real estate investors' interests in its exchange value is favorable to deregulation and urban growth. Before the current crisis began, the ability of the local hotel chains, (who are the most powerful capitalist elite in these islands), to develop their activity abroad (for instance in The Caribbean and Central America [38]) favored their support of urban growth constraints and regulation in Majorca. Nowadays, these investors and elites have changed towards supporting a more flexible regulation that will allow them to increase their gains within the local real estate tourism market.

The ex-post legalization of irregular houses built in urban sprawl without planning permissions may be considered the strongest deregulation nowadays that serves to deal with the crisis through regional planning relaxation. This last deep change in the rural planning has been established through Law 7/2012, regarding "urgent measures for sustainable urban planning" [39]. Undoubtedly, the name given to this Law is a good example of the use of rhetoric in this neoliberal regulatory shift.

Further to this urban planning amnesty for illegal rural dwellings, a parallel legalization has been developed by the tourism administration of the Balearic Islands. It began with an urgent decree law to boost investment [40] that opened an extraordinary procedure of regularization of tourist places, only for the following eight months, which theoretically finished on the 2 October 2009. Eventually, a new Tourism Law [41] extended this extraordinary period for one year from its approval; until 21 July 
2013. Information given at the regional Parliament by the Balearic Islands Ministry of Tourism shows some results of this regularization process: 108 beds in holiday villas were legalized in 2011 and 1,907 more in 2012, with earnings of more than 10 million Euros from their fees to the public administration [42]. Additionally, the new Tourism Law (8/2012) [41] allows changing the use of tourist accommodation businesses, which were until now strictly forbidden. This was in order to make possible partial sale as investment stocks for capital fixation, through the secondary circuits of capital accumulation. Its purpose is to attract global capital, which is illustrated by the fact that a special issue of the Official Gazette published with the Law is available online in English and even Russian. Dealing with the urban sprawl process, this last law allows the legalization of holiday villas that began in 2009 with a government decree law [40], permitting the use of structures and auxiliary buildings for the operation of rural tourism establishments. This process legalizes the development of structures and auxiliary buildings that have or have had a use other than residential, for any kind of use, including accommodation, thus bringing these parts of the built environment into the real estate tourism market.

In the following sections, spatial analyses are described that show urban land changes associated with these policy and planning developments. In particular, the related urban sprawl processes in inland Majorca are discussed.

\section{Materials and Methods}

The approach to the study of the linkages between real estate tourism and urban sprawl in Majorca combines different sources of information and scales of analysis. Based on CORINE Land Cover data (1990 and 2006) [10], the urbanization process is analyzed at low resolution scale $(1: 100,000)$. This analysis is carried out at municipality level, including demographic data. Different processes and dimensions of urban sprawl are captured:

- Creation of new urban fabric (1990-2006, hectares per $\mathrm{km}^{2}$ urban fabric).

- Change in urban density (1990-2006, inhabitants per $\mathrm{km}^{2}$ urban fabric).

Urban sprawl is often considered to be expressed by the dynamics of urban growth, which is captured by the amount of creation of new urban fabric. Another aspect of urban sprawl is de-densification, which is indicated by the negative change in urban density. This occurs in cases where growth of urban fabric is higher than demographic growth, reducing the indicator (inhabitants per $\mathrm{km}^{2}$ urban fabric) for the later observation (here, the year 2006) compared to the earlier observation or point in time (here, the year 1990). We hypothesize that there is a relationship between the growth of urban fabric, residential tourism and demographic change in Majorca and that differences can be observed at municipality level. We therefore test if there are correlations between the creation of new urban fabric, the number, density and percentage of second homes, and changes in urban density.

To show the results of analyses at municipality level, three variables are related in a two-dimensional graph to depict the variation in change in discontinuous urban fabric, change in urban density and proportion of second homes per municipality or exurban swimming pool density. The combination of this information with data on the percentage of second homes per municipality allows a differentiation between municipalities where this kind of suburban sprawl happens. Empirical data on second homes is somewhat problematic, but the most comprehensive source is the 2001 census of 
population and housing in Spain [12]. This census enumerates buildings and classifies them as secondary family dwellings, meaning that they are housing that is not considered to be the principal residence and for which the use type can be: for only part of the year, as a real estate investment or to be rented for tourist purposes. This extensive suburban sprawl is characterized by a low density, spacious residential matrix of large plots occupied by gardens and swimming pools. These developments are due to the growth in residential areas for permanent dwelling and other extensive urban areas more oriented to second residences for locals or tourists.

Available statistics on second homes do not allow to allocate them spatially, i.e., to decide whether they are located inside or outside the officially demarcated urban areas. Accepting this limitation of the data, exurban swimming pools are used as a proxy for two related aspects and processes of urban sprawl. Firstly, swimming pools are related to an increase of low-density residential areas characterized by large plots that allow the maintenance of a garden and a swimming pool $[43,44]$. Secondly, swimming pools are leisure amenities that increase return on investment in the second-home rental market [45]. Thus, analyzing the number of swimming pools is based on the premise that they have become standard features of suburban areas in Spain and are indicators of affluence and social status, which has already been shown in similar studies [43]. Currently there are few new semi-detached or low-rise residential developments in Majorca that do not include a swimming pool. Given the lack of data and studies on the phenomenon of second homes, the study on the market value of the attributes that explain the overall price of second-home rentals [44] is indicative of the importance that swimming pools have for return on investment; so we hypothesize that the presence of swimming pools is related to second home usage.

Finally, the recent process of holiday villas legalization is taken as a confirmation test to link this tourism model shift with the countryside exurban sprawl.

The analyses outlined in the subsequent sections are guided by the following hypotheses:

- The creation of new urban fabric in an urban sprawl pattern is related to real estate tourism indicated by a positive correlation with the number and density of second homes at municipality level.

- Municipalities with a change in urban density have a high proportion of second homes to principal residences, because second homes are primarily located in a low-density urban fabric that has increased faster over time than population (i.e., urban density decreased over time).

- The creation of new urban fabric is related to second home development for which the absolute number and density of exurban swimming pools is indicative.

- The growing number of countryside villas, often with swimming pools, is fed by tourist and real estate investors attracted by this new product. The ongoing process of countryside villas and holiday villas' legalization is driven by these capital investors.

- These land use changes have their main driver in the neoliberal economic and urban planning policies; particularly through the relaxation, weakening, flexibilization or lifting of regional planning to attract capital flows, exacerbated within the crisis context.

Illustrating the analysis approach (Figure 3) makes clear that the linkages between urban sprawl and real estate tourism in Majorca are complex and multi-layered and that hypotheses, explanatory 
variables, and indicators may overlap to some extent. These limitations are mainly grounded in the limited data availability on second homes, including the difficulties of allocating them spatially to urban or exurban land. Consequently, the empirical analyses make use of indicators and proxies and some results are qualitative rather than a strict testing of hypotheses.

Figure 3. Scheme of the empirical approach to analyze the types of development (suburban and exurban sprawl), showing the explanatory variables and the indicators by which the variables are measured.

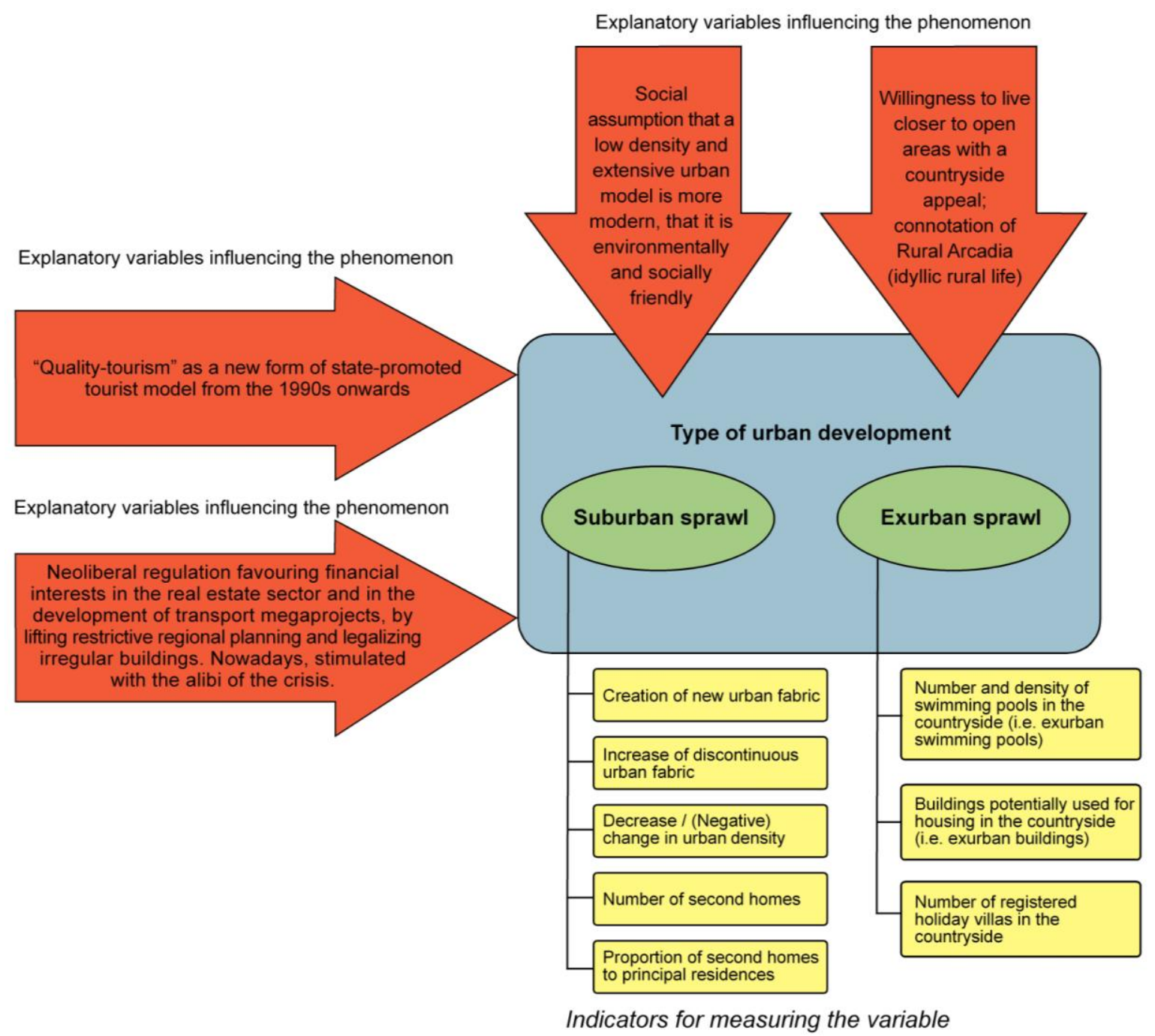

\subsection{Spatial Analysis of Suburban Sprawl Processes from 1990 to 2006}

Based on CORINE Land Cover data (1990 and 2006), changes in urban land are analyzed in two dimensions. Most research defines urban sprawl by referring to a measure of density. Sprawl is that kind of urban expansion where the rate of land consumption is higher than the increase in population density. At the same time, sprawl is understood as a process over time, an exurban land use change where low-density expansion of urban areas results in the spread of discontinuous, polycentric and more dispersed urban land uses in the countryside [44]. Consequently, the present analysis looks at the process of growth of continuous and discontinuous urban fabric and the change in urban density in the 53 municipalities from 1990 to 2006. Urban density is defined as the number of inhabitants per $\mathrm{km}^{2}$ 
artificial surfaces (urban fabric, industrial, commercial and transport units, mine, dump and construction sites, and artificial, non-agricultural vegetated areas). For municipalities exhibiting high changes in urban fabric and urban density, the percentage of second homes is calculated based on the most recent housing census in 2001 [12]. The percentage of second homes relative to principal residences is looked at as an additional explanatory variable to identify different sprawl processes; in particular the localities where urban sprawl is driven by real estate tourism. The density of swimming pools in the countryside is another indicator for second homes used as holiday villas. The number of legalized houses built outside of urban areas that after legalization have become listed in the official tourist accommodation register is an additional indicator for the linkage between urban sprawl and real estate tourism.

\subsection{Spatial Analysis of Exurban Development of Buildings and Swimming Pools in the Countryside}

Urban sprawl into the Majorcan countryside, this is exurban sprawl, must be considered as a different process within a different framework. First, the scale of CORINE land cover data is too coarse to identify the urban land uses of many isolated constructions (with dwellings and swimming pools). But they can be identified through a more detailed analysis through the latest Topographic Map of the Balearic Islands (MTB 1:5,000). And secondly, exurban sprawl is framed by a very different regional and urban planning regulatory framework. Until now, this framework has restricted the construction of such isolated buildings in the countryside, and the extraordinary fact is that now there is a process of ex-post legalization with amnesty of irregularities. This legalization process is shown here by discussing how recent changes in legislation and regulations from both the urban planning and the tourist management administrations are promoting this amnesty. This evolution of urban sprawl in Majorca is documented by an analysis of buildings located in the countryside, comparing the situation in 1987 (from a 1:50,000 scale map) and in 1999 (estimated for a 1:25,000 scale map) [46] with our own calculation based on the latest Topographic Map of the Balearic Islands (created from a photogrammetric flight dated in 2006, and with a resolution of 1:5,000 scale). The method used for the analysis of the recent map allows us to discard buildings not devoted to human dwelling, which is an improvement in relation to the method used for the 1987 and 1999 surveys. The total amount of buildings in the countryside is assessed and has differentiated which dwellings can certainly be used as residential houses; for instance, excluding warehouses that are assumed not to be conditioned for this purpose. In addition, an inventory of swimming pools is derived from this Topographic Map of the Balearic Islands (2006).

\subsection{An Approach to the Analysis of Holiday Villas Distribution Pattern in Majorca's Countryside}

Pattern analyses of this urban sprawl allow us to differentiate the most important areas where this process occurs. A Geographical Information System-ESRI ArcGIS $\odot$ (Redlands, CA, USA)—has been used to estimate the density values on a grid of density values. This grid has been analyzed through the Kernel density method ( $250 \mathrm{~m}$ analysis cell size), which is a non-parametric way to estimate the probability density function of a random variable. Density estimation with a kernel is based on the calculation of magnitude per unit area from discrete features using a kernel function to fit a smoothly tapered surface to each observation. Kernel density estimations are calculated as densities of swimming pools in a neighborhood around these features of urban sprawl associated with leisure 
purposes and second home development. The resulting density surface is a map that shows where and how swimming pools are concentrated across the landscape.

\section{Results and Discussion}

\subsection{Urban Sprawl in Majorca (1990-2006)}

Analysis of CORINE land cover data shows that artificial surfaces have increased by $42.9 \%$ in the $2 \mathrm{~km}$-wide coastal strip and by $96.6 \%$ in the countryside beyond the coast (1990-2006). In the same period, the proportion of artificial surfaces located at the coast has decreased from $54.4 \%$ to $46.4 \%$ which underscores the change in urban pattern on the island [47]. This urban growth was accompanied by a population increase of 31.5\%. Bivariate correlations analysis in IBM SPSS Statistics Software 19 package was used to compute the correlation between indicators of urban sprawl, demographic change, transformations of the built environment and residential tourism. The results indicate that swimming pools are features that are in general related with urban growth in Majorca (Table 1).

Table 1. Correlation matrix between urban sprawl indicators.

\begin{tabular}{cccc}
\hline Variable & $\begin{array}{c}\text { Creation of } \\
\text { New Urban Fabric }\end{array}$ & $\begin{array}{c}\text { Change in Urban } \\
\text { Density }\end{array}$ & $\begin{array}{c}\text { Number of Exurban } \\
\text { Swimming Pools }\end{array}$ \\
\hline Number of second homes & $0.398^{* *}$ & - & $0.528^{* *}$ \\
Proportion of second homes to principal residences & - & $0.335^{*}$ & - \\
Density of second homes (per km $\left.{ }^{2}\right)$ & $0.436^{* *}$ & - & $0.304^{*}$ \\
Number of exurban swimming pools & $0.325^{*}$ & - & n.a. \\
Density of exurban swimming pools $\left(\right.$ pools $\left./ \mathrm{km}^{2}\right)$ & $0.498^{* *}$ & - & n.a. \\
\hline
\end{tabular}

** correlation is significant at the 0.01 level (2-tailed), * correlation is significant at the 0.05 level (2-tailed), - not significant, n.a. not applicable.

Moreover, the absolute number of second homes and the density of second homes in the housing stock are positively and significantly correlated with the creation of new urban fabric in the period of 1990 to 2006. This result corroborates the hypothesis that the creation of new urban fabric is related to real estate tourism. Densification of settlements has occurred where the relative importance of second homes in the housing stock is high, indicating that there was a tendency of population influx in municipalities where second homes were built. The creation of second home real estate was a precursor of demographic change, and second home owners progressively registered with the municipalities' registration offices. This interpretation is underscored by an increase of urban houses in the course of the ongoing cadastral revision. The fact that the number of urban houses in the cadastre has increased can be attributed not only to urban growth but also to the fact that exurban residences have been included in the cadastre in order to make them pay the property tax (IBI, Impuesto sobre Bienes Inmuebles), in the process of the aforementioned amnesty of irregularities. Presence of second homes and swimming pools are positively and significantly correlated in absolute and relative (density) terms. Swimming pools are indicative of second home development, which is consistent with our hypothesis, although this result cannot be interpreted unambiguously given the fact that swimming pools have become features of low density residential development in general and are not limited to second homes. 


\subsection{Urban Sprawl Patterns at Municipality Level in Majorca (1990-2006)}

In order to exploit the data further, the density of exurban swimming pools is graphically related to two other variables: changes in urban density and increase in discontinuous urban fabric, which by definition is linked with urban sprawl [3]. Secondly, change in urban density, discontinuous urban fabric and density of exurban swimming pools are illustrated to highlight municipalities that exhibit different urban sprawl patterns and driving forces (Figure 4). Illustrating the municipalities' change in discontinuous urban fabric and urban density over time (1990-2006) shows differences in relation to sprawl and de-densification versus sprawl and densification. In combination with a third variable (second home percentage or swimming pool density in the countryside), urban sprawl in relation to second home development at the coast or in the countryside can be identified (Figures 4 and 5).

Figure 4. Exurban swimming pool density (radius of the bubble) plotted against change (1990-2006) in discontinuous urban fabric (y-axis) and change in urban density (x-axis) in selected municipalities in Majorca. Data source: Own calculations based on 1:5,000 Topographic Map of the Balearic Islands, 2006, and [10].

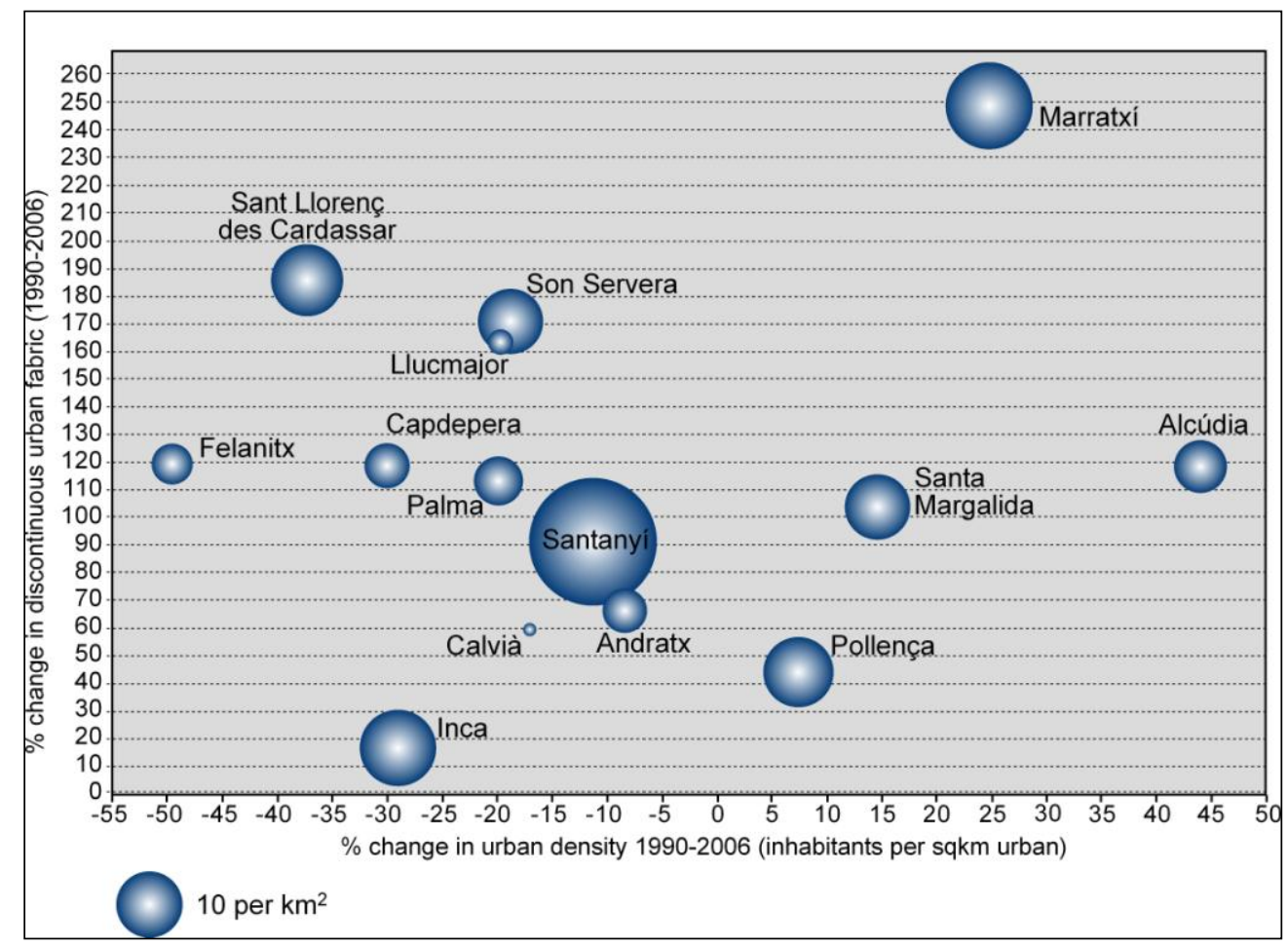

In combination, the ratio of second homes to principal residences, expressed as $\%$ shows that different urban sprawl processes (Figure 5) have occurred simultaneously: firstly, coastal municipalities like Andratx and Calvià that have very high ratios of second homes to principal residences have experienced moderate de-densification and urban sprawl. Secondly, coastal municipalities like Santa Margalida, Pollença or Alcúdia with medium to high ratios of second homes have a densification of the urban system in terms of population density compared to urban fabric. Sprawl has occurred here as well, indicating low-density urban growth. A third group consists of municipalities like Felanitx, Santanyí, Son Servera, Sant Llorenç des Cardassar and Capdepera that show urban sprawl related to second homes used as holiday villas in the countryside. Lastly, the fourth 
category is represented by the municipality of Marratxí that exhibits both sprawl and a high increase in urban density, which is typical for municipalities at the urban fringe of Palma, the island's largest city and metropolitan region. The complete opposite development happened in the inland municipality Inca, which experienced high-density urban growth decoupled from its demographic development. Like in Plama and Marratxí, second home development is only marginally coupled to urban sprawl; rather growth in discontinuous urban fabric is linked to residential uses. On the premise that swimming pool density in exurban areas is indicative of second homes in the countryside, adding this data gives some interesting modifications to the pattern (Figure 4). In Calvià and Andratx, second homes and most swimming pools are close to urban areas at the coast. In contrast, there are medium to high densities of pools in the countryside in places with very low ratios of second homes, i.e., in Inca, Marratxí, Sant Llorenç des Cardassar and Santanyí. This observation is in accordance with other studies that have shown the commoditization of swimming pools as a feature related with suburbanization and low-density residential development in Spain, irrespective of second home expansion [43]. The empirical findings show that further research is needed to better understand the relationship between change in urban density and proportion of second homes (compare the second hypothesis, Section 3).

Figure 5. Ratio of second homes to principal residences (radius of the bubble) plotted against change (1990-2006) in discontinuous urban fabric (y-axis) and change in urban density (x-axis) in selected municipalities in Majorca. Data source: Own calculations based on $[10,12]$.

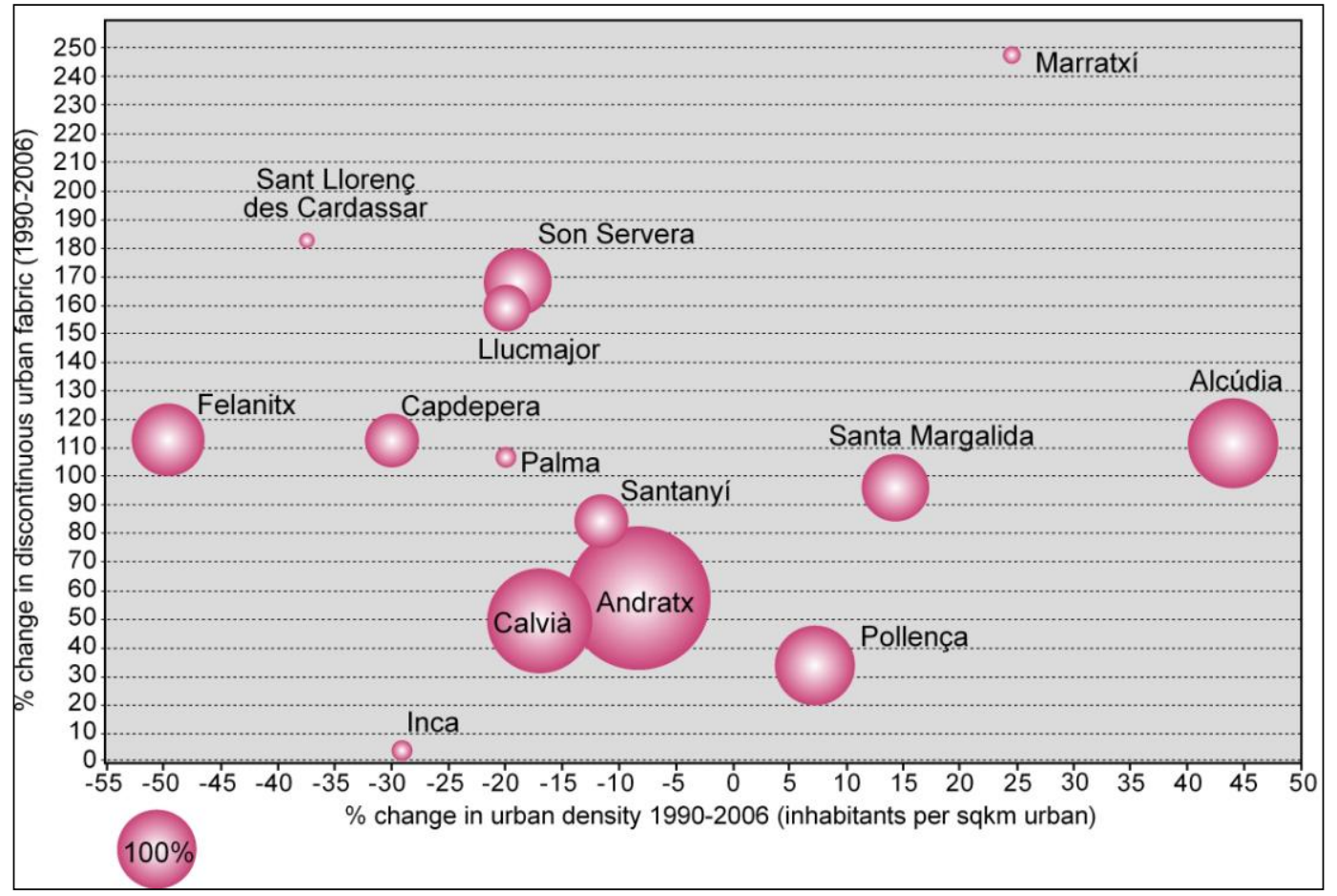

The analysis results discussed above are based on zonal map algebra calculations with the CORINE land cover data in ArcGIS 10, and the attributes are combined with attributes on swimming pool density and second home percentages at municipality level. These are spatially implicit and highly aggregated indicators of the urban sprawl processes that are linked to real estate tourism. In the 
following sections, the results of spatially explicit analyses are described, exploiting the spatial detail of the current Topographic Map of the Balearic Islands (at 1:5,000 scale) for a comparison of exurban sprawl patterns and differences between suburban and countryside exurban sprawl.

\subsection{Urban Sprawl for Real Estate Tourism in Majorca: Villa Construction in Majorca's Countryside}

The evolution of urban sprawl in Majorca shows a steady increase of buildings located in the countryside: from 53,354 in 1987 (data established through the analysis of a 1:50,000 scale map) to 74,000 in 1999 (estimated for a 1:25,000 scale map) [46]. Our own calculation on the latest Topographic Map of the Balearic Islands (created from a photogrammetric flight dated in 2006, and with a resolution of 1:5,000 scale) shows a higher amount of 226,590 isolated constructions in the countryside (Figure 6). The method used allows us to discard buildings not devoted to human dwelling, which is an improvement in relation to the method used for the 1987 and 1999 surveys.

Figure 6. Swimming pools associated with human dwellings usable as residential houses in Majorca from the Topographic Map of the Balearic Islands (2006), reprinted with permission from Sitibsa S.A., Palma (Majorca). Northernmost empty areas correspond to mountainous terrains.

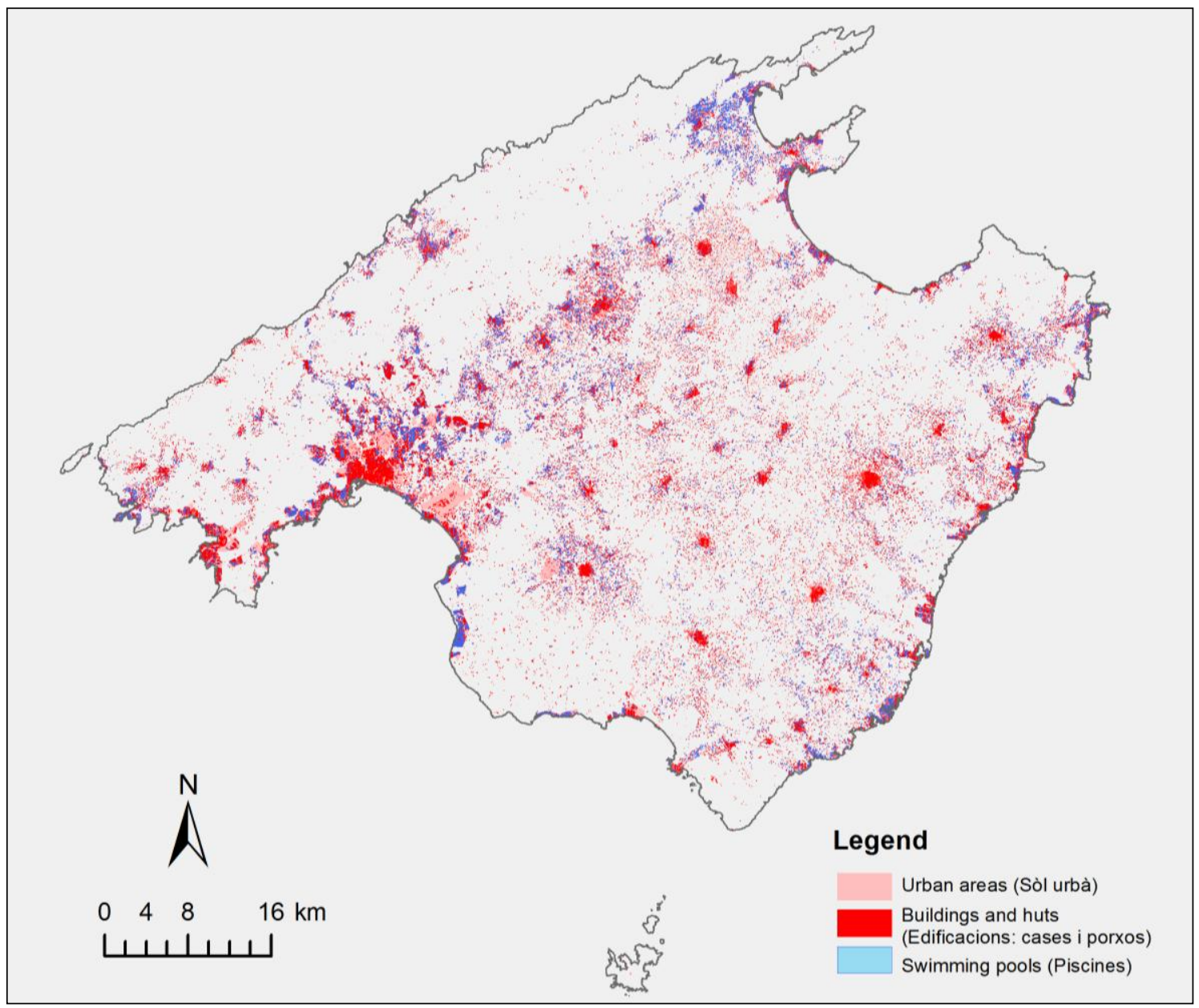

The above mentioned total amount of buildings in the countryside, 226,590, includes all kinds of construction: houses, huts, storehouses, swimming pools, ponds, etc. The classification of the 
Topographic Map allows us to establish that 180,087 are dwellings (79.4\%) that can certainly be used as residential houses; for instance, excluding warehouses that are assumed to not be conditioned for this purpose. Additionally, 40,567 swimming pools are present in Majorca, $46 \%$ of which $(18,621)$ are located outside of the urban areas.

The analysis of the Topographic Map of the Balearic Islands (2006) shows the urban sprawl intensification of Majorca, reaching 226,590 buildings, which is 4.3 times more than in 1987. A more detailed account of the number of dwellings $(180,087)$ and swimming pools $(18,621)$ allows us to identify the areas where this use is growing, significantly changing the face of the countryside. According to our hypothesis, this is due to the financial interest of investing capital in this kind of real estate.

Pollença, which is located at the northernmost bay, is notably the municipality where more swimming pools have been built in the countryside, and also where more holiday villas have been legalized. The case of this municipality has already been analyzed because of the increasing urban sprawl which is a cause of concern [48].

\subsection{Holiday Villas and Swimming Pool Distribution Pattern in Majorca's Countryside}

Pattern analyses of this urban sprawl allow us to distinguish three different geographical conditions where this process occurs: seaside suburban developments, metropolitan suburban developments and exurban rural areas that are separate from the urban system (Figure 7).

Figure 7. Results of kernel density analysis on the swimming pools associated with human dwellings usable as residential houses in Majorca. Data source: Own calculations based on the Topographic Map of the Balearic Islands (2006), used with permission from Sitibsa S.A., Palma (Majorca).

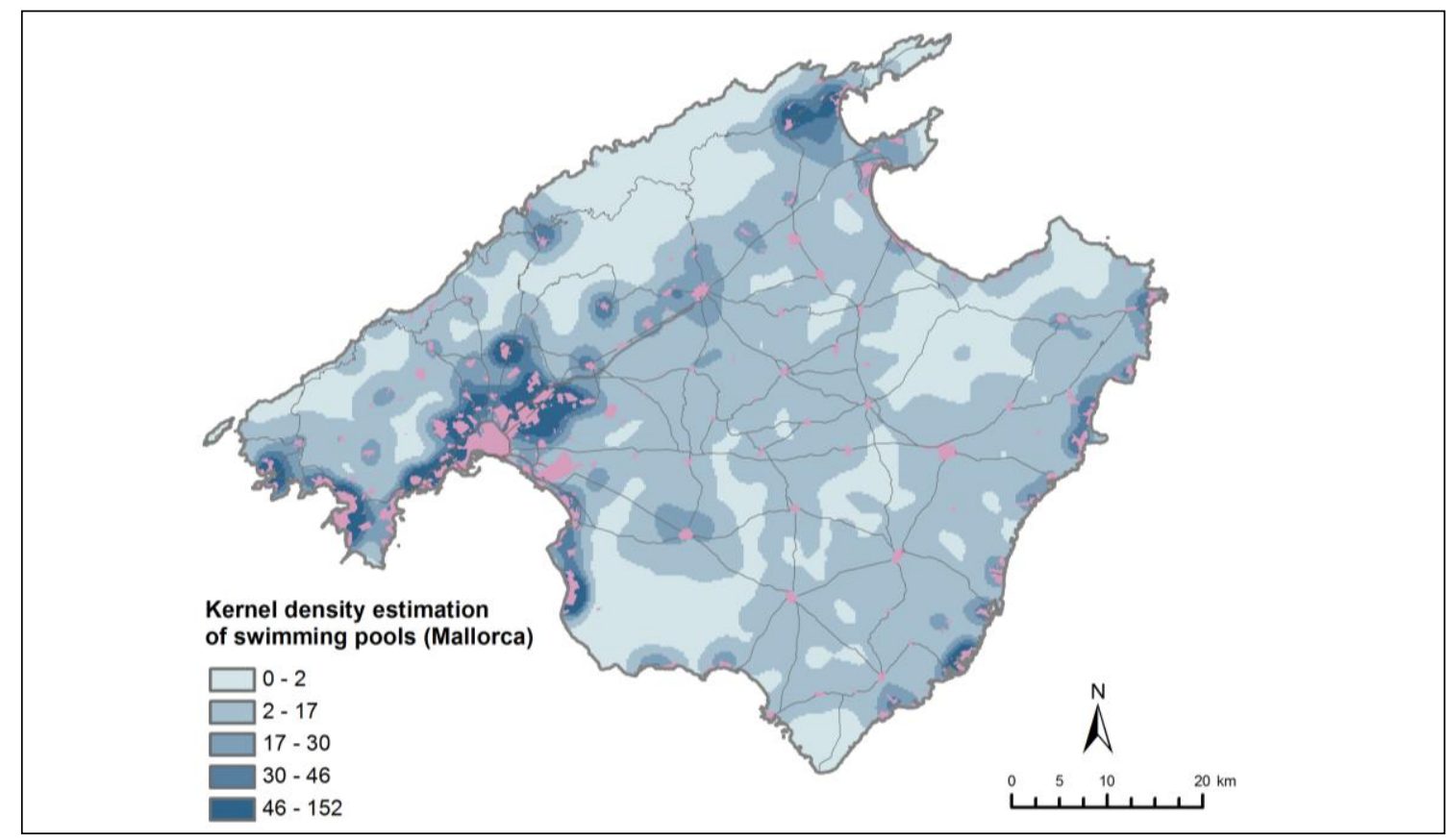


Swimming pool presence can be considered an unquestionable characteristic of leisure facilities. Firstly, they are mainly present in the seaside suburban developments (Palma, Calvià, Andratx, Llucmajor, Santanyí, Sant Llorenç, Alcúdia, and Capdepera). As Figure 7 shows, these resorts constitute formal urban developments, although they are extensive in terms of land use pattern. They are mainly devoted to tourism real estate markets for those international elites interested in the highest standards and profitability rates. For example, an analysis of the market value of the attributes that explain the overall price of second-home rentals in the Costa Brava in Spain has shown that a second home with a swimming pool is $26 \%$ more expensive than accommodation without this facility. Out of 13 explanatory variables analyzed, only beach distance has a more pronounced effect on price, and only home size has an effect on profitability that is as strong as that of a swimming pool, followed by extra rooms, terrace/garden size and sea views [44]. Secondly, most of the swimming pools are located inland in the surrounding areas of the capital city of Palma, located in the southwest bay. This metropolitan area is characterized by suburban developments of expensive residential areas, mainly for high income Majorcan people.

A third group of areas with a high density of swimming pools is characterized by the exurban sprawl in rural areas out of the formal urban system, particularly in: Pollença, Sóller, Alaró, Inca, and Llucmajor. These areas are occupied by two different kinds of newcomers with second homes: local people and foreigners. Both groups of people are involved in second home functions and the real estate business of these dwellings with swimming pools through selling or renting them. While the first group has the advantage of owning more land by inheritance, the second group of newcomers has more capital to invest. The distribution of the swimming pools located in the countryside by municipalities is shown in Table 2 and Figures 4, 6, 7 and 8.

The pattern of the swimming pools distribution in the countryside shows its concentration in high quality countryside locations, at the rural valleys of the mountain ranges close to the sea (Figure 7). These are the cases of: Pollença at the northern bay, Andratx in the southwest of the island, Santa Margalida at the northeast bay, and the southeast coasts from Santanyí to Sant Lorenç, Son Servera and Capdepera. The maps show how this distribution of the swimming pools in the countryside correlates with the municipalities with the highest ratios of second homes (Figure 8). Their attractiveness for tourists is making them targets for real estate investment in countryside villas.

Table 2. Swimming pool distribution in the countryside in Majorca, by municipalities. Data source: 1:5,000 Topographic Map of the Balearic Islands (2006).

\begin{tabular}{cccc}
\hline Municipality & Municipality Area km & Number of Swimming Pools & Density per $\mathbf{~ k m}^{\mathbf{2}}$ \\
\hline Pollença & 151.1 & 1,568 & 10.4 \\
Palma & 195.5 & 1,393 & 7.1 \\
Manacor & 260.0 & 1,229 & 4.7 \\
Llucmajor & 327.0 & 1,122 & 3.4 \\
Felanitx & 169.6 & 965 & 5.7 \\
Marratxí & 54.2 & 708 & 13.1 \\
Santanyí & 37.6 & 674 & 17.9 \\
Inca & 58.3 & 623 & 10.7 \\
Artà & 139.7 & 564 & 4.0 \\
Andratx & 81.4 & 540 & 6.6 \\
\hline
\end{tabular}


Table 2. Cont.

\begin{tabular}{|c|c|c|c|}
\hline Municipality & Municipality Area km² & Number of Swimming Pools & Density per $\mathbf{k m}^{2}$ \\
\hline Sencelles & 48.7 & 517 & 10.6 \\
\hline Algaida & 89.7 & 477 & 5.3 \\
\hline Alcúdia & 59.9 & 433 & 7.2 \\
\hline Bunyola & 84.6 & 407 & 4.8 \\
\hline Son Servera & 42.5 & 399 & 9.4 \\
\hline Sant Llorenç & 38.5 & 374 & 9.7 \\
\hline Selva & 124.4 & 373 & 3.0 \\
\hline Capdepera & 54.9 & 352 & 6.4 \\
\hline Binissalem & 29.8 & 320 & 10.8 \\
\hline Santa Maria & 86.5 & 297 & 3.4 \\
\hline Alaró & 45.7 & 291 & 6.4 \\
\hline Calvià & 144.9 & 243 & 1.7 \\
\hline Campos & 149.5 & 225 & 1.5 \\
\hline Porreres & 86.8 & 216 & 2.5 \\
\hline Esporles & 35.3 & 196 & 5.6 \\
\hline Santa Margalida & 20.2 & 191 & 9.4 \\
\hline Campanet & 34.6 & 177 & 5.1 \\
\hline Montuïri & 41.1 & 175 & 4.3 \\
\hline Sineu & 47.7 & 175 & 3.7 \\
\hline Sóller & 42.7 & 159 & 3.7 \\
\hline Costitx & 15.4 & 155 & 10.1 \\
\hline Muro & 58.6 & 154 & 2.6 \\
\hline Lloseta & 12.1 & 149 & 12.3 \\
\hline Ses Salines & 39.0 & 149 & 3.8 \\
\hline Petra & 70.1 & 147 & 2.1 \\
\hline Sant Joan & 52.8 & 126 & 2.4 \\
\hline Valldemossa & 42.8 & 114 & 2.7 \\
\hline Llubí & 34.9 & 109 & 3.1 \\
\hline Puigpunyent & 48.6 & 106 & 2.2 \\
\hline Santa Eugènia & 82.0 & 102 & 1.2 \\
\hline Búger & 8.3 & 97 & 11.7 \\
\hline Consell & 13.7 & 96 & 7.0 \\
\hline Lloret & 17.4 & 94 & 5.4 \\
\hline Deià & 15.1 & 77 & 5.1 \\
\hline Fornalutx & 19.5 & 65 & 3.3 \\
\hline Maria & 30.5 & 53 & 1.7 \\
\hline Banyalbufar & 18.0 & 45 & 2.5 \\
\hline Estellencs & 13.4 & 44 & 3.3 \\
\hline Ariany & 23.0 & 43 & 1.9 \\
\hline Mancor & 19.9 & 37 & 1.9 \\
\hline Sa Pobla & 42.3 & 28 & 0.7 \\
\hline Vilafranca & 23.9 & 21 & 0.9 \\
\hline Escorca & 139.2 & 20 & 0.1 \\
\hline Total & 4.5 & 18,621 & 4.1 \\
\hline
\end{tabular}


Figure 8. Swimming pool density in the countryside, exurban, and the importance of second home ownership in Majorca, by municipalities. Data source: 1:5,000 Topographic Map of the Balearic Islands (2006) and own calculations, base on [12].

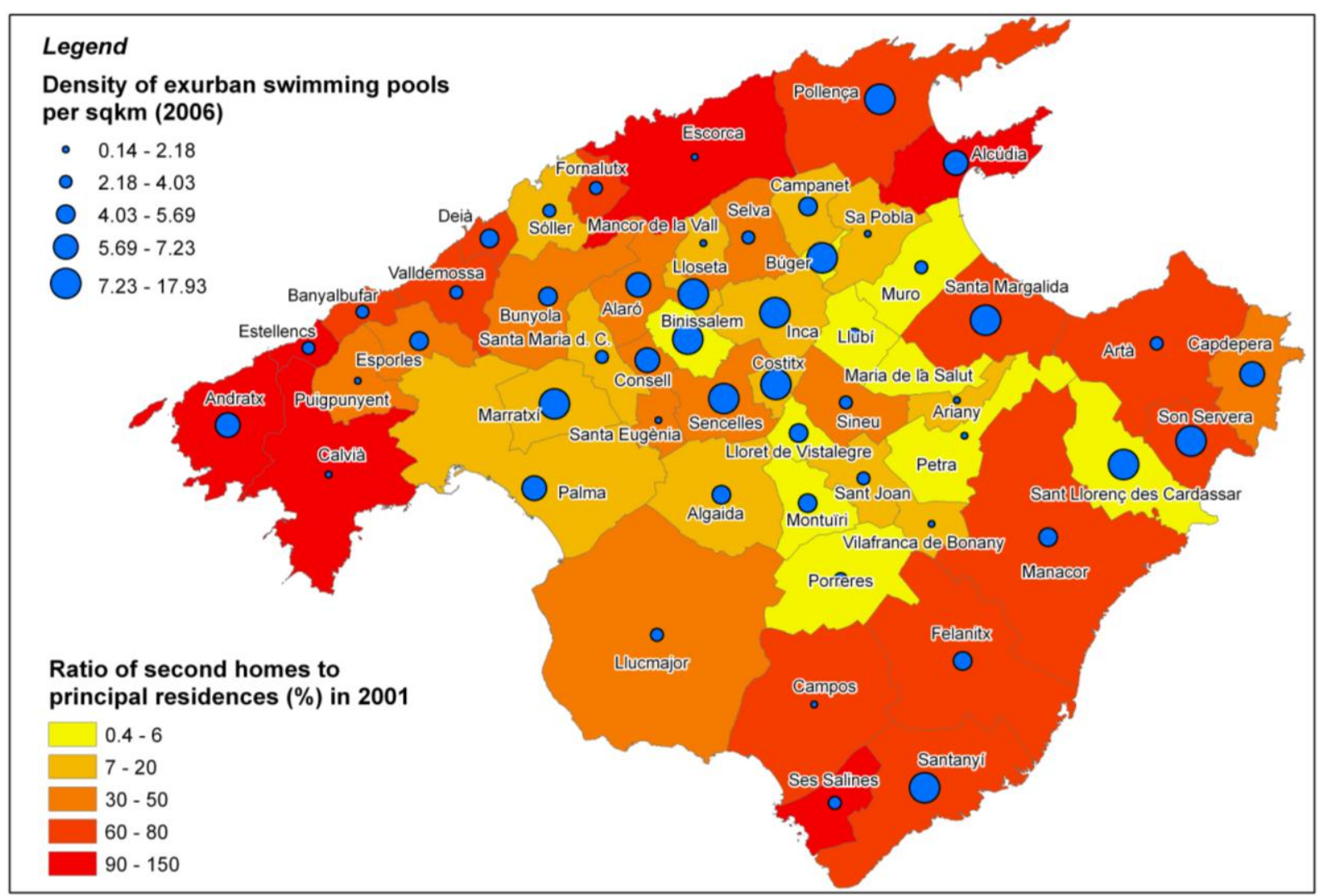

Secondly the urban sprawl that appears around the biggest cities and along the main road corridors is chosen by Majorcan people for their second residence developments.

This social segregation shows that newcomers to the countryside, tourists and the local population, occupy different areas according to their different income rates. While tourists own or rent holiday villas close to the mountain ranges and the seafront, the local population keeps for their own leisure purposes those second home countryside houses located near the biggest cities and the main arterial roads, such as the central corridor from Palma to Inca.

While the metropolitan areas of Palma, Manacor, Llucmajor, Marratxí and Inca are preferred by the local population to locate their own second homes, the more privileged locations are mainly reserved for real estate tourist purposes. Looking at its density per squared kilometer, the highest (17.9 swimming pools per $\mathrm{km}^{2}$ ) is again found in Santanyí, mainly for real estate tourism purposes. Pollença, Sant Llorenç, Santa Margalida, Son Servera and Alcúdia are also municipalities with high swimming pool density (from 7 to 10 per $\mathrm{km}^{2}$ ). In accordance with our hypothesis, they are also chosen for real estate tourism purposes.

\subsection{Holiday Villas Legalization Process}

The legalization of houses built in urban sprawl areas and their registration as tourist accommodation, described above in detail by outlining the deregulation process from 2008 onwards (Section 2.3), has provided for, as a result, a new public register of holiday villas that can confirm the 
relationship between urban sprawl and real estate tourism in Majorca. This public register shows the amount of villas that can be legally marketed as tourist accommodation. Its distribution shows that Pollença had more than $34 \%$ of the total amount of beds allocated for this kind of accommodation in 2010, followed by Santanyí and Felanitx that have in sum more than 28\% (Table 3).

Table 3. Public register of holiday villas in Majorca, 2010. Conselleria de Turisme, Govern de les Illes Balears.

\begin{tabular}{|c|c|c|}
\hline & Holidays Villas Open in 2010 & Number of Beds \\
\hline Pollença & 495 & 1,983 \\
\hline Santanyí & 195 & 1,002 \\
\hline Felanitx & 106 & 626 \\
\hline Alcúdia & 72 & 248 \\
\hline Calvià & 125 & 225 \\
\hline Santa Margalida & 60 & 222 \\
\hline Sant Llorenç & 50 & 198 \\
\hline Ses Salines & 81 & 186 \\
\hline Andratx & 54 & 179 \\
\hline Son Servera & 33 & 164 \\
\hline Capdepera & 46 & 148 \\
\hline Campos & 11 & 68 \\
\hline Manacor & 18 & 60 \\
\hline Selva & 7 & 55 \\
\hline Búger & 8 & 54 \\
\hline Muro & 6 & 51 \\
\hline Artà & 8 & 39 \\
\hline Palma & 36 & 37 \\
\hline Campanet & 5 & 29 \\
\hline Inca & 3 & 27 \\
\hline Sa Pobla & 3 & 22 \\
\hline Sineu & 2 & 16 \\
\hline Llucmajor & 2 & 14 \\
\hline Sóller & 1 & 14 \\
\hline Sencelles & 1 & 12 \\
\hline Porreres & 1 & 8 \\
\hline Valldemossa & 1 & 8 \\
\hline Algaida & 1 & 6 \\
\hline Alaró & 0 & 0 \\
\hline Total & 1,431 & 5,701 \\
\hline
\end{tabular}

This source of information allows us to ratify the use differentiation among the resident population and real estate tourism. In accordance with our hypothesis, this concentration of holiday villas already legalized to go into the rental market coincides with the countryside areas with the highest concentration of swimming pools.

According to this data, some of the areas with a higher density of swimming pools in the countryside are also areas where more legal holiday villas are openly devoted to tourist 
accommodation: Santanyí, Pollença, Sant Llorenç, Santa Margalida and Son Servera. These municipalities share the qualities of: having the highest densities of swimming pools in the countryside, the highest amounts of legalized holiday villas and being away from the primary urban system within a second range of rural villages. Therefore, the tourist real estate use of the increasing urban sprawl can be established, at least initially, for these municipalities.

\section{Conclusions}

Tourists who used to come to Majorca for a stay in a hotel are nowadays increasingly renting accommodation in the real estate tourism sector, or may be acquiring their second residences on the island. The real estate market gains profit from its exchange value, which is a way of capital accumulation through its secondary circuit. The improvements of accessibility through megaprojects of transport infrastructure contribute to this process of time-space compression within the European real estate tourism market. Majorca positions itself as a real estate property market and adds properties' financial attractiveness to its traditional appeal for sun and sea tourism. Neoliberal responses to the crisis are to attract global capital, driven by its overaccumulation and liberalization of movements, into new urban growth. Land use development trends of suburban and exurban sprawl are linked to several kinds of neoliberal regional planning: the legalization of holiday villas or the allowance of tourist accommodation use changes and rebuilding urban developments, even though they may be in areas already protected by nature conservation designations. Neoliberalism is also promoting capital and investment unbridling, since the Maastricht Treaty agreements (1992). Spain has become reliant on FDI, mainly interested in real estate investment. This is why current policies are changing the consensus on the urban growth constraints in the Balearic Islands, through the relaxation of regional planning rules in order to attract capitals flows towards new real estate markets. Accordingly, its solutions to the current crisis are legalizing and promoting urban sprawl.

Different patterns of urban sprawl are identified: Firstly, the suburban developments preferred by investors and tourist as second residences by the seaside; secondly, the suburban metropolitan developments that attract local people for residential purposes; and finally, exurban sprawl, within a pattern of very low density, that is becoming the new tourist option of rental holiday villas. Swimming pool presence is characteristic in all three categories of urban sprawl.

This paper has delved into an analysis of a multilayered process that is not only dynamic over time, but exhibits non-uniform spatial patterns. The analysis has focused on spatial and statistical data at different relevant scales of analysis to come to grips with the lack of official statistics and comprehensive data. This poses methodological difficulties for research into second home and real estate tourism. In fact, the phenomena of second home and real estate tourism are not captured by statistics because their impact in terms of urban and demographic growth is perceived as side-effect of "tourism" and economic rejuvenation and modernization. Consequently, these sectors are meanwhile important contributors to the tourist economy, particularly in Spain, but their material impact on the transformation of the urban and built environment has so far received less attention than the impact on social and cultural aspects. In this context, the present analysis has unveiled some of the linkages and causal relationships between several relevant, but certainly not all, variables that interact to bring about the spatial pattern of urban change in the island of Majorca. Established coastal mass tourist resorts 
have extended their tourist base on the coast by an expansion of low-density, discontinuous fabric with an almost exclusively residential purpose. In some, this expansion has already spilled over to the countryside, which is a process for which swimming pool density is an indicator. At the same time, inland municipalities have experienced urban growth, which in some cases is related to second home expansion and residential tourism. More extended spatial analysis focusing on different clusters of municipalities with similar patterns of urban sprawl (suburban versus exurban, for example) will be the focus of further research.

There are several limitations of the data used and consequently, gaps in the analysis of the data. Available statistics do not allow inferences about the instigators of housing development or inferences about the actors involved. Power struggles to take gains' control from real estate tourism markets in Majorca have been studied by Ivan Murray [28,49] and deserve to be investigated in further research. In-depth data collection in selected sub-municipal districts as part of future research could be one way to overcome these limitations. However, it is speculative if in-field data collection will be easy in this context. Tourist use of private houses is all but uncommon in Spain and estimates are that the actual dimension of this accommodation is several times higher than that offered in the regulated tourist accommodation business [50,51]. In other words, the second-home rental market is not very transparent and some of the revenue generated in this tourist segment may elude taxation and other regulation. There are other methodological constraints related with these aspects that may additionally hamper the feasibility of such a research approach. For example, issues of confidentiality and protection of privacy may impede household interviews for identifying the nationality of the homeowners, for identifying the instigators of building or neighborhood development (municipality, real estate companies, private owners), or for finding out whether a particular house is used as second or principal residence.

Notwithstanding these limitations, the present paper gives insights into urban sprawl patterns at different spatial and temporal scales. Summing up and confirming our hypotheses, it has been shown that: Firstly, second homes proliferate in new urban fabric areas, and there is also a growth of isolated dwellings and holiday villas in the countryside. Secondly, second homes, isolated dwellings, and holiday villas all have in common that they are improved with the construction of swimming pools. Thirdly, this urban growth is driven by capital investment interested not only in its use value, but also in its exchange value. And last but not least, the interests in these investments are promoting a new regulatory framework of flexibilization and ex-post legalization.

\section{Acknowledgements}

This research was funded by a project entitled "Geographies of the Crisis: analysis of the urban-tourist spaces of the Balearic Islands, Costa del Sol and the most important tourist destinations of the Caribbean and Central America", (CSO2012-30840) for the Spanish Ministry of Economy and Competitiveness. It has also received financial support from the European Regional Development Fund and from the Department of Universities, Research and Knowledge Transfer, of the Ministry of Education, Culture and Universities of the Autonomous Community of the Balearic Islands. We thank Jerònia Ramon for her support with the GIS analysis and mapping production and three anonymous reviewers and Aileen Salway for their helpful comments. 


\section{Conflict of Interest}

The authors declare no conflict of interest.

\section{References}

1. Casado-Diaz, M.A. Socio-demographic impacts of residential tourism: A case study of Torrevieja, Spain. Int. J. Tourism Res. 1999, 1, 223-237.

2. Mantecón, A. Tourist modernisation and social legitimation in Spain. Int. J. Tourism Res. 2010, $12,617-626$.

3. European Environment Agency (EEA). Urban Sprawl in Europe-The Ignored Challenge; EEA: Copenhagen, Denmark/Luxembourg, 2006.

4. Barke, M. Second homes in Spain: An analysis of change at the provincial level, 1981-2001. Geography 2007, 92, 195-207.

5. Parés, M.; March, H.; Saurí, D. Atlantic gardens in Mediterranean climates: Understanding the production of suburban natures in Barcelona. Int. J. Urban Reg. Res. 2012, 37, 328-347.

6. Iglesias, A.; Garrote, L.; Flores, F.; Moneo, M. Challenges to manage the risk of water scarcity and climate change in the Mediterranean. Water Resour. Manag. 2007, 21, 775-788.

7. Buswell, R.J. Mallorca and Tourism-History, Economy and Environment; Channel View Publications: Bristol, UK, 2011.

8. Bardolet, E.; Sheldon, P.J. Tourism in archipelagos: Hawai'i and the Balearics. Ann. Tourism Res. 2008, 35, 900-923.

9. Schmitt, T.; Blázquez, M. Der dritte tourismusboom auf Mallorca (1991-2000). Zukunftsweisender trend oder überschrittener Zenit? Tourism. J. 2003, 7, 505-522.

10. European Environment Agency (EEA). Corine Land Cover (1990, 2000, 2006) Raster Data; European Environment Agency: Copenhagen, Denmark, 2012.

11. Balearic Tourism Research and Technologies Centre (CITTIB). Conselleria de Turisme: Dades Informatives; Conselleria de Turisme: Palma, Spain, 2006.

12. Instituto Nacional de Estatística (INE). INEbase/Demography and Population/Population Figures and Demographic Censuses-Population Figures 1970-2011; Population and Housing Census. Available online: http://www.ine.es/en/inebmenu/mnu_cifraspob_en.htm (accessed on 29 January 2013).

13. Molotch, H. The city as a growth machine: Toward a political economy of place. Am. J. Sociol. 1976, 82, 309-332.

14. Harvey, D. Fixed Capital, the Consumption Fund and the Accumulation of Capital. In The Limits to Capital; Verso: London, UK, 1999; pp. 235-238.

15. Brenner, N.; Theodore, N. Spaces of Neoliberalism: Urban Restructuring in North America and Western Europe; Blackwell: Oxford, UK, 2002.

16. López, I.; Rodríguez, E. The Spanish model. New Left Rev. 2011, 69, 3.

17. Gobierno de España, Ministerio de Fomento, Estadísticas Sobre Transacciones Inmobiliarias (Compraventa) Según Residencia del Comprador. Available online: http://www.fomento.gob.es (accessed on 27 February 2013). 
18. Institut d'Estadística de les Illes Balears (IBESTAT). Estadísticas: Economía, Comercio e Inversión Exterior: Inversiones Exteriors; 2012. Available online: http://www.ibestat.cat/ibestat/ page (accessed on 15 February 2013).

19. Balearic Islands Business and Investment Guide; Govern de les Illes Balears, Ministry of Economy Business and Employment Promotion: Palma, Spain, 2012.

20. Artigues, A.A. Funcionalización Turística y Proceso de Urbanización en la Isla de Mallorca. In Introducción a la Geografía Urbana de las Illes Balears. Guía de Campo del VIII Coloquio y Jornadas de Campo de Geografía Urbana; Artigues, A.A., Bauzà, A., Blázquez, M., González, J.M., Murray, I., Rullán, O., Eds.; Grupo de Geografía Urbana AGE: Palma, Spain, 2006; pp. 110-162.

21. Smith, N. Towards a theory of gentrification: A back to the city movement by capital not people. J. Amer. Plann. Assn. 1979, 45, 538-548.

22. Phillips, M. Rural gentrification and the processes of class colonisation. J. Rural Stud. 1993, 9, 123-140.

23. Phillips, M. Other geographies of gentrification. Progr. Hum. Geogr. 2004, 28, 5-30.

24. McCarthy, J. Rural geography: Globalizing the countryside. Progr. Hum. Geogr. 2007, 32, 129-137.

25. Sckalair, L. The transnational capitalist class and the discourse of globalization. Camb. Rev. Int. Aff. 2000, 14, 67-85.

26. Bauzà, A. Spatio-Temporal Fix and Time-Space Compression: Transport Mega-Projects and Tourism Development in Mallorca. In Proceedings of the International Conference on Environmental Conflicts and Justice, Barcelona, Spain, 2-3 July 2010.

27. The Order of 31st of July 2001 of Approval of the Director Plan for the Airport of Palma (Majorca). In Spanish Official Bulletin (BOE); Num. 221 (14/9/2001); 2001 Available online: http://www.fomento.gob.es/NR/rdonlyres/C0E94033-6DAD-4667-84E4-A65090197BBC/67525/ OrdenMinisterial.pdf (accessed on 22 May 2013).

28. Murray, I. Geografies del Capitalisme Balear. Poder, Metabolisme Socieconòmic i Petjada Ecològica d'una Superpotència Turística. Ph.D. Thesis, University of the Balearic Islands, Palma Spain, 2012.

29. Flyvbjerg, B.; Bruzelius, N.: Rothengatter, W. Megaprojects and Risk. In An Anatomy of an Ambition; Cambridge University Press: Cambridge, UK, 2003.

30. Harvey, D. The New Imperialism; Oxford University Press: Oxford, UK, 2003; Volume 115.

31. Morey, M. Disúrbia. Recull de Notícies 2000-2004; Maties Morey Ripoll: Valldemossa, Spain, 2007.

32. Kondo, M.C.; Rivera, R.; Rullman, S. Protection the idyll but not the environment: Second homes amenity migration and rural exclusion in Washington State. Landscape Urban Plan. 2012, 106, 174-182.

33. Rullan, O. Las políticas territoriales en las Islas Baleares. Cuadernos Geográficos 2010, 47, 403-428.

34. van Slingerlandt, A.B. Insular Land Use Planning on the Balearic Islands (Spain): Weak or Strong Sustainability? In the Proceedings of the Inaugural Meeting of the IGU Commission on Islands-Island Geographies International Conference, Taipei, Taiwan, 29 October-3 November 2007; Volume I, pp. 4-20. 
35. Peck, J.; Tickell, A. Neoliberalizing space. Antipode 2002, 34, 380-404.

36. Sandberg, L.A.; Wekerle, G.R. Reaping nature's dividends: The neoliberalization and gentrification of nature on the Oak Ridges moraine. J. Environ. Pol. Plann. 2010, 12, 41-57.

37. Keil, R. The urban politics of roll-with-it neoliberalization. City Anal. Urban Trends Cult. Theor. Pol. Action 2009, 13, 230-245.

38. Blázquez, M.; Cañada, E.; Murray, I.; Playa-Sol, B. Conflictos derivados de la construcción de enclaves de capital transnacional turístico español en El Caribe y Centroamérica. Scripta Nova. Revista Electrónica de Geografía y Ciencias Sociales 2011, 15, 368.

39. Law 7/2012, of Urgent Measures for a Sustainable Urban Planning; In the Official Gazette of the Balearic Islands (BOIB); Num. 91 (23/6/2012). Available online: http://boib.caib.es/pdf/2012091/ mp4.pdf (accessed on 27 February 2013).

40. Decree Law 1/2009 on Urgent Measures for Investment in the Balearic Islands. In the Official Gazette of the Balearic Islands; Núm. 17 (2/2/2009). Available online: http://boib.caib.es/pdf/ 2009017/mp2.pdf (accessed on 27 February 2013).

41. Law 8/2012 on Tourism in the Balearic Islands, Dated the 19th of July. In the Official Gazette of the Balearic Islands (BOIB); Num. 106 (21/7/2012). Available online: http://www.caib.es/ govern/archivo.do?id=1224364 (accessed on 27 February 2013).

42. Journal of Plenary Sessions of the Balearic Parliament Dated the 11th of December 2012; VIII Legislature; Num. 67, 2785. Available online: http://www.parlamentib.es/ca/publicacions/ Detalle.aspx?criteria=2\&year=2012 (accessed on 27 February 2013).

43. Vidal, M.; Domene, E.; Saurí, D. Changing geographies of water-related consumption: Residential swimming pools in suburban Barcelona. Area 2010, 43, 67-75.

44. Meeus, S.J.; Gulinck, H. Semi-urban areas in landscape research: A review. Living Rev. Landscape Res. 2008, 2. Available online: http://www.livingreviews.org/lrlr-2008-3 (accessed on 29 February 2012).

45. Saló, A.; Garriga, A. The second-home rental market: A hedonic analysis of the effect of different characteristics and a high-market-share intermediary on price. Tourism Econ. 2011, 17, 1017-1033.

46. Rullan, O. Edificis aïllats o residències?, àrees singulars o regions úniques?, "booms" o desenvolupaments?, espai rural o sòl rústic? Scripta Nova. Revista Electrónica de Geografía y Ciencias Sociales 2007, 11, 232.

47. Cabellos, M. Islas Balears-Tensión Entre Destrucción y Protección. In DeCOASTruction. La Desconfiguración del Litoral Mediterráneo Español; Gaja, F., Ed.; Universitat Politècnica de València: Valencia, Spain, 2012; pp. 128-253.

48. Mateu, J. Turismo residencial y dispersión urbana en Mallorca (Illes Balears)-Un ensayo metodológico en el municipio de Pollensa. Estudios Turísticos 2003, 155-156, 197-218.

49. Murray, I.; Blázquez, M.; Amer, J. Doblers, poder i territori de "marca balear" (1983-2009). J. Catalan Stud. 2011, 13, 321-350.

50. Cámara de Comercio de Mallorca. Estudio Sobre la Situación del Turismo Residencial en las Illes Balears-Conclusiones. Servicio de Estudios y Publicaciones-Cámara de Comercio de Mallorca: Palma, Spain, 2006. 
51. Deloitte y Exceltur. Impactos Sobre el Entorno, la Economía y el Empleo de los Distintos Modelos de Desarrollo Turístico del Litoral Mediterráneo Español, Baleares y Canarias; Exceltur-Alianza Para la Excelencia Turística: Madrid, Spain, 2005.

(C) 2013 by the authors; licensee MDPI, Basel, Switzerland. This article is an open access article distributed under the terms and conditions of the Creative Commons Attribution license (http://creativecommons.org/licenses/by/3.0/). 